\title{
Determinants of smallholder sweet potato farmers' participation in different market options: The case of Vihiga County, Kenya
}

\author{
Benjamin K. Mutai ${ }^{1}$, Elvi N. Agunda ${ }^{2 \star}$, Augustus S. Muluvi ${ }^{3}$, Lawrence K. Kibet ${ }^{3}$ and \\ Mary C. Maina ${ }^{1}$ \\ ${ }^{1}$ Department of Agricultural Economics/Agribusiness Management at Egerton University, Njoro Campus, Kenya. \\ ${ }^{2}$ Department of Agricultural Economics/Agribusiness Management, Egerton University, Kenya. \\ ${ }^{3}$ Department of Economics, Egerton University, Kenya.
}

Accepted 10 June, 2013

\begin{abstract}
Market participation has a potential to increase farmers' rural incomes and employment opportunities especially if farmers concentrate on production and marketing of local crops requiring low inputs such as sweet potatoes. The purpose of this research was to investigate the factors that determine farmers' shift in market participation from village to regional market in Vihiga County. Cross-sectional data was collected and a multinomial logit model was used for the analysis. Participation in local town market rather than village market was influenced by credit access, total income, transport mode to market, access to extension services, age, value addition done and the quantity of sweet potatoes supplied, while; transport mode, land size, quantity of sweet potatoes and gender determined participation for the regional option. It is recommended that the local and national government should: Increase its support in the establishment of sweet potato market; improve the rural road networks to cut down transport costs, and increase support to farmer groups or associations to increase farmers' market participation.
\end{abstract}

Key words: Determinants, smallholder sweet potato farmers, participation, market options.

\section{INTRODUCTION}

Poverty in Africa has been found to be predominantly a rural phenomenon. About $75 \%$ of the world's poor are believed to work and live in rural areas, and it is estimated that, by the year $2020,60 \%$ of the poor will still be rural (Olwande and Mathenge, 2010). According to Omiti et al. (2009), agriculture supports the livelihoods of about $80 \%$ of the rural population in Kenya (about $85 \%$ of them being small-scale farmers). Only $22 \%$ of land in Kenya is arable though another $40 \%$ has potential for irrigated agriculture. The agricultural sector employs $70 \%$ of the national labor force through forward and backward industrial linkages, thus providing food and incomes to individuals and households (Omiti et al., 2009). Smallscale agriculture in Kenya is characterized by landholdings of less than 5 acres and no more than 20 ruminant animals (mainly cattle, sheep and goats) and a few chickens per farming household (Omiti et al., 2009). Crop-livestock production systems on small scale farms often entail very little use of purchased inputs and limited application of modern technology with majority of farmers producing for subsistence. Meeting the challenge of reducing poverty and improving rural incomes in Kenya 
will require some form of transformation out of the semisubsistence production systems that currently characterize much of rural Africa to a more commercialized agriculture (Komarek, 2010). Omiti et al. (2009) in their study were of the opinion that commercial orientation of smallholder agriculture leads to a gradual decline in real food prices due to increased competition and lower costs in food marketing and processing.

Vihiga is one of the poorest and densely populated Counties in Kenya with an average household land size of 0.4 ha (FAO, 2007). According to Karanja (2006) the main food crops grown in the area are maize, beans, sorghum, finger millet, Irish potatoes, sweet potatoes, cassava and vegetables, while the main industrial ones are coffee, tea and sugar cane. The causes of poverty could be attributed to limited land, high poverty levels, and limited off-farm incomes. According to MOPND (2005), about $62 \%$ of the population (in what was by then) Vihiga District lives in absolute poverty and about $60 \%$ of the population is poor. Maize is the staple food for the residents of Vihiga thus its insufficiency is synonymous to food insecurity. Over the decade (1997 to 2006), the County's demand for maize outpaced the production level, worsening the already bad food situation (Nyangweso, 2007). This could be attributed to diminishing land sizes because of the increase in population, high costs of inputs for maize production thus making it uneconomical for production.

With the growing food crisis and high prices of mainstream food crops such as maize, there is a growing recognition of the importance of local crops such as sweet potatoes in supporting livelihoods for the poor. Rono et al. (2007) in their study in the North Rift Valley region of Kenya, which has almost similar agro-climatic conditions as Vihiga, found that $75 \%$ of the farmers get sweet potatoes from their own farms, $22 \%$ from the market and $1 \%$ get from their neighbors.

This crop has the potential to diversify the farming systems, spread risks, contribute to food security, and provide income opportunities for the most vulnerable and women in particular. If sweet potato commercialization efforts are to be put in place then a majority of the farmers would be better off. According to CPPMU (2010), the area under sweet potato production in Kenya in 2009 increased by $24 \%$, production in tones by $16 \%$ while the unit price per $100 \mathrm{~kg}$ bag in Kenya shillings in various markets increased by $43 \%$.

Despite this increase in production and prices, not all farmers participate in markets. According to Omiti et al. (2009), 52\% of rural farmers, sweet potato included, participate in markets where they sell only less than $50 \%$ of their produce to the various market options. The factors that make the sweet potato farmers not to increase their participation especially in the regional market options are not clear and hence the need to investigate them through establishing the market options available and further determine what socio-economic characteristics determine participation in the different market options.

\section{MATERIALS AND METHODS}

\section{Econometric model}

To analyse the choice of market option, the multinomial logit model, whereby the dependent variable is the choice of market option while the independent variables are the explanatory variables predicted to have an influence on the choice of the market option, was used. According to Greene (2002), the model has a single decision among two or more alternatives. Unordered choice models can be motivated by a random utility model. For the $\mathrm{i}^{\text {th }}$ farmer faced with $\mathrm{j}$ choices, suppose that the utility of choice $\mathrm{j}$ is:

$U_{i j}=Z_{i j}^{\sigma} \beta+\varepsilon_{i j}$

If farmer makes choice $\mathrm{j}$ in particular, then we assume that $\mathrm{U}_{\mathrm{ij}}$ is the maximum among the $\mathrm{j}$ utilities. Hence the standard model will be driven by the probability that choice $\mathrm{j}$ is made which is,

Probability $\left(U_{i j}>U_{i k}\right)$ for all other $\mathrm{k} \neq \mathrm{j}$

Assuming that $\mathrm{Yi}$ represents the choice taken, then with $\mathrm{J}$ disturbances being distributed identically and independently, the multinomial logit model will be represented as follows:

$\operatorname{Pr} o b(Y i=j)=\frac{e^{\beta j x i}}{\sum_{k=0}^{J} e^{\beta k x i}}$, where $\mathrm{j}=0,1 \ldots \ldots \ldots . . . J$

Equation 3 represents a multinomial logit model, that can provide a set of probabilities for the $J_{+} 1$ choices for the decision taker with characteristics $x_{i}$. This means that we can compute $\mathrm{J}$ log-odds ratio as in equation 4 below. From the point of view of estimation, it is useful that the odds ratio $\mathrm{Pj} / \mathrm{Pk}$ does not depend on other choices which follow from the independence of disturbances in the original model (Greene, 2002).

$\operatorname{In}\left(\frac{P i j}{P i k}\right)=x_{i}\left(\beta_{j}-\beta_{k}\right)=x_{i} \beta_{j}$ if $\mathrm{k}=0$

Based on Equation 4, according to Greene (2002) and Mugisha et al. (2004) and the fact that farmers participate some times in more than one market option, their participation in different market options are categorized into alternatives, using those who participated in the village market option as the base alternative because it was common. The other alternatives include selling to neighbors (immediate neighbor with buyer and seller sharing a common boundary), local town and regional market options. Therefore, the multinomial logit regression model estimated 3 Equations (5, 6 and 7) simultaneously (Studenmund, 1992). The 3 equations are specified as:

$$
\begin{aligned}
& \ln \left(\frac{p_{i}}{p_{o}}\right)=Z_{i}=\alpha_{o}+\alpha_{1} X_{1}+\alpha_{2} X_{2}+\ldots \ldots \ldots \alpha_{11} X_{11}+\varepsilon_{i} \\
& \ln \left(\frac{p_{g}}{p_{o}}\right)=Z_{e}=\beta_{o}+\beta_{1} X_{1}+\beta_{2} X_{2}+\ldots \ldots \ldots \beta_{11} X_{11}+\varepsilon_{g} \\
& \ln \left(\frac{p_{u}}{p_{o}}\right)=Z_{u}=\gamma_{o}+\gamma_{1} X_{1}+\gamma_{2} X_{2}+\ldots \ldots \ldots \gamma_{11} X_{11}+\varepsilon_{u}
\end{aligned}
$$


Table 1. Variables used in multinomial logit model.

\begin{tabular}{|c|c|c|c|}
\hline Variable & Description & Unit of measurement & Expected signs \\
\hline Totinc $^{a}$ & Monthly total income & Kenya shillings & $(+)$ \\
\hline Sacks $^{a}$ & Sacks of sweet potatoes taken to market option & $100 \mathrm{Kg}$ bags & $(+)$ \\
\hline Vadon^ & Value addition done to sweet potatoes & $\begin{array}{l}\text { Dummy }(1=\text { sorting, washing and packing, } 0 \\
=\text { otherwise) }\end{array}$ & $(+)$ \\
\hline Acext $^{\wedge}$ & Access to sweet potato extension services & Dummy $(0=$ no, $1=$ yes $)$ & $(+)$ \\
\hline Accrdts $^{\wedge}$ & Access to credit & Dummy $(0=$ no, 1 = yes $)$ & $(+)$ \\
\hline Educ $^{a}$ & Education level & Years & $(+)$ \\
\hline $\mathrm{Age}^{\mathrm{a}}$ & Age & Years & $(+)$ \\
\hline Totassbas $^{a}$ & Total asset base & Kenya Shillings & $(-)$ \\
\hline Trusop^ & Transport used to option(s) & Dummy $(1=$ better, $0=$ otherwise $)$ & $(+)$ \\
\hline Totland $^{\mathrm{a}}$ & Total land owned & Acres & $(+)$ \\
\hline Gend^ $^{\wedge}$ & Gender of farmer & $(1=$ male, $0=$ female $)$ & $(+)$ \\
\hline Hhsize $^{a}$ & Household size & No of males/females & $(-)$ \\
\hline
\end{tabular}

${ }^{\mathrm{a}}=$ Natural logarithm, ${ }^{\wedge}=$ dummy variables .

Where $p o=$ probability that a household chose to participate in the village market option (base alternative); $P i, P e$ and $P u=$ the probability that a household chose to participate in the local town, regional and neighbor market options respectively; $Z i, Z e$ and $Z u=$ household participates in the local town, regional and neighbor market options, respectively ( 1 if household participates, 0 otherwise); $\alpha o, \beta o$ and $y_{0}=$ intercepts showing probability of participating in the local town, regional and neighbor market option respectively, if all other explanatory variables are kept constant at zero; $\alpha i, \beta i$ and $y i=$ parameters of the ith set of local town, regional and neighbor market options respectively that are estimated, and $X i$ $=$ explanatory variables of the market option participation $\varepsilon i, \varepsilon O$, and $\varepsilon u$ are the error terms.

\section{Data collection}

The data used in the analysis was collected between the months of May and June, 2011 in 3 divisions, Vihiga, Luanda and Sabatia in Vihiga County which were selected based on the population density. Random samples of 38,48 and 34 sweet potato farmers both participating in markets and otherwise were selected from Luanda, Sabatia and Vihiga respectively, resulting to a total sample size of 120. Data was collected using interview schedules collecting information on farm and farmer characteristics, transaction costs and market related factors. Table 1 presents definitions for the variables used in the multinomial logit model.

\section{RESULTS}

Table 2 presents the descriptive statistics of the sweet potato farmers found to participate in the different market options available in Vihiga County. Sweet potato farmers who mainly sell their produce to the regional markets have the largest average land acreage of 4.03 , followed by $3.03,2.1$ and 2 acres for local town, village and neighbor market options, respectively.

Land size was found to significantly vary across participants of the different markets options. Farmers owning larger farms engaged more in a wider market ranging from participant in neighborhood market with land size of 2 acres to that in the regional market of 4.4 acres. Income from sweet-potatoes and value addition were positively related to market participation thus explaining the monetary incentives that make the larger market other than the village market attractive to the farmers.

Table 3 presents a cross-tabulation of the market options and socio-economic characteristics of the farmers in discrete values such as gender, access to credit and extension. With regards to gender, $50 \%$ of female and $50 \%$ of males participated in the market. Majority $(57.1 \%)$ are participating in the village market with females being $34.3 \%$ while males are $22.9 \%$.

The socio-economic characteristics determining the various market options which farmers participate in are given in Table 4. According to the results from the multinomial logit model, $60.9 \%$ of the variation in the categorical dependent variable was explained by the model. The village market option is chosen as the base market option since it is common across all the 3 options and every other choice is then compared to the base.

\section{DISCUSSION}

Analysis of the data show that, total land ownership was significantly different at $10 \%$ level hence influencing choice of the farmer's market option. Land was a critical production asset having a direct bearing on production of a marketable surplus (Machethe et al., 2008). Means of the average distance to the farmers' market option was also significantly different with the farthest market option being regional with an average distance of 257, followed by 27.21 and $4.7 \mathrm{~km}$ for local town and village. The distances represent the geographical coverage of the market with the regional market being the largest and the village market being the smallest. 
Table 2. Descriptive statistics of the participant farmers in the different market options.

\begin{tabular}{|c|c|c|c|c|c|c|}
\hline \multirow{3}{*}{ Variable } & \multirow{3}{*}{$\begin{array}{l}\text { Overall mean } \\
\quad(n=70)\end{array}$} & \multicolumn{5}{|c|}{ Main market options } \\
\hline & & \multicolumn{5}{|c|}{ Means } \\
\hline & & $\begin{array}{l}\text { Neigh } \\
(n=1)\end{array}$ & $\begin{array}{l}\text { Village } \\
(n=40)\end{array}$ & $\begin{array}{c}\text { Local town } \\
(n=24)\end{array}$ & $\begin{array}{l}\text { Regional } \\
(n=5)\end{array}$ & F-Test \\
\hline Age & $45.23(12.92)$ & 48 & $44.22(13.52)$ & $47.75(12.91)$ & $40.60(7.99)$ & 0.604 \\
\hline Household size & $5.16(2.50)$ & 5 & $5(2.48)$ & $5.54(2.73)$ & $4.6(1.82)$ & 0.316 \\
\hline Total land owned & $2.58(1.87)$ & 2 & $2.1(1.32)$ & $3.03(2.14)$ & $4.4(3.05)$ & $3.239^{*}$ \\
\hline Education & $10.24(3.03)$ & 8 & $9.73(3.19)$ & $10.83(2.93)$ & $12(0)$ & 1.462 \\
\hline Months per season & $3.99(0.53)$ & 4 & $4.03(0.62)$ & $3.96(0.20)$ & $3.805(0.84)$ & 0.296 \\
\hline Distance & $30.4(76.5)$ & 0 & $4.7(5.2)$ & 27.21(39.07) & $257(144.5)$ & $52.26^{*}$ \\
\hline Sweet potato income & $2074(1868)$ & 750 & $1477(1377)$ & $2764(2090)$ & $3805(2448)$ & $4.705^{\star}$ \\
\hline Cost of value addition & 283.28(479.9) & 25 & $127(148)$ & $526(714)$ & $420(435)$ & $4.221^{*}$ \\
\hline
\end{tabular}

${ }^{*}$ Significance level of $10 \%$.

Table 3. Descriptive statistics of the participant farmers in discrete variables.

\begin{tabular}{lccccccc}
\hline \multirow{3}{*}{ Variable } & & \multicolumn{5}{c}{ Market options } \\
\cline { 3 - 8 } & & $\begin{array}{c}\text { All } \\
(\mathbf{n = 7 0})\end{array}$ & $\begin{array}{c}\text { Neighbor } \\
(\mathbf{n = 1})\end{array}$ & $\begin{array}{c}\text { Village } \\
(\mathbf{n}=\mathbf{4 0})\end{array}$ & $\begin{array}{c}\text { Local town } \\
(\mathbf{n}=\mathbf{2 4})\end{array}$ & $\begin{array}{c}\text { Regional } \\
(\mathbf{n}=5)\end{array}$ & Chi-square \\
\hline \multirow{3}{*}{ Gender } & Female & 50 & .0 & 34.3 & 12.9 & 2.9 & 0.231 \\
& Male & 50 & 1.4 & 22.9 & 21.4 & 4.3 & \\
& Total & 100 & 1.4 & 57.1 & 34.3 & 7.1 & \\
Extension & & & & & & & \\
services & No & 58.6 & 1.4 & 41.4 & 11.4 & 4.3 & $0.017^{*}$ \\
& Yes & 41.4 & .0 & 15.7 & 22.9 & 2.9 & \\
& Total & 100 & 1.4 & 57.1 & 34.3 & 7.1 & \\
Credit & & & & & & & \\
& No & 77.1 & 1.4 & 45.7 & 25.7 & 4.3 & 0.711 \\
& Yes & 22.9 & .0 & 11.4 & 8.6 & 2.9 & \\
\hline
\end{tabular}

${ }^{*}$ Significance level of $10 \%$.

Mean income from sweet potato across the market options was statistically different at $10 \%$ level. This income influences the choice of market option because it increases the farmers' cash resources and hence could result in investment of sweet potato marketing. The highest average income, Kshs. 3805, was received by farmers selling to the regional market probably because of the good sweet potato prices. The mean cost of value addition is Kshs. 283.28 which is inclusive of water fees, labor for sorting the sweet potatoes and packaging materials for majority of the farmers. The cost was statistically different across the groups with those preferring local town markets incurring the highest average of Kshs. 526, followed by regional (Kshs.420) and Kshs. 127 for village.

Access to credit gives the farmer more cash resources hence it has an effect on his/her sweet potato marketing activities. According to the results, access to credit was significant at $10 \%$ level and negatively influences local town market participation. As the credit status of the sweet potato farmer changes from not accessing it to accessing, the probability of participating in the local town market than village reduces by $34.3 \%$ implying that the farmer will sell fewer sweet potatoes in the local town market as compared to the village market. This is inconsistent with the priori positive sign (Asfaw et al., 2010) likely because the farmer may increase participation of other farm and off-farm activities which are perceived to be more lucrative such as cash crops and dairy products. The margins from these alternatives are likely larger than sweet potatoes thus enabling the farmer to meet repayment of the credit and have some savings for his needs. Additionally, the study population was made up of smallholder farmers who have so diverse 
Table 4. Model Estimates of the determinants of market option participation by farmers.

\begin{tabular}{|c|c|c|c|c|}
\hline Variable & Coefficient & $\mathbf{z}$ & $p>|z|$ & Marginal effects \\
\hline \multicolumn{5}{|l|}{ Local town market option } \\
\hline Household size & $0.99(0.89)$ & 1.12 & 0.262 & 0.224 \\
\hline Credit access & $-1.94(1.14)$ & -1.70 & $0.088^{*}$ & -0.343 \\
\hline Total asset base & $-0.48(0.47)$ & -1.02 & 0.310 & -0.108 \\
\hline Total income & $0.99(0.57)$ & 1.73 & $0.084^{*}$ & 0.222 \\
\hline Transport mode to option & $1.28(0.49)$ & 2.62 & $0.009^{*}$ & 0.287 \\
\hline Access to extension & $2.04(0.92)$ & 2.23 & $0.026^{*}$ & 0.446 \\
\hline Total land owned & $0.75(0.81)$ & 0.93 & 0.352 & 0.168 \\
\hline Education & $-1.41(1.07)$ & -1.31 & 0.191 & -0.316 \\
\hline Sacks taken to option & $1.05(0.63)$ & 1.68 & $0.094^{*}$ & 0.235 \\
\hline Value addition done & $0.98(0.49)$ & 2.02 & $0.043^{*}$ & 0.220 \\
\hline Age & $-3.24(1.49)$ & -2.17 & $0.030^{*}$ & -0.727 \\
\hline Gender & $0.98(0.88)$ & 1.11 & 0.266 & 0.218 \\
\hline \multicolumn{5}{|l|}{ Regional market option } \\
\hline Household size & $1.33(3.44)$ & 0.39 & 0.699 & $3.49 \mathrm{e}-06$ \\
\hline Access to credit & $-0.92(4.26)$ & -0.22 & 0.830 & $1.28 \mathrm{e}-06$ \\
\hline Total asset base & $-5.02(3.27)$ & -1.53 & 0.125 & -0.00002 \\
\hline Total income & $2.37(2.83)$ & 0.84 & 0.401 & $7.16 e-06$ \\
\hline Transport mode to option & $6.52(3.25)$ & 2.00 & $0.045^{*}$ & 0.00002 \\
\hline Access to extension & $-9.18(7.11)$ & -1.29 & 0.196 & -0.00022 \\
\hline Total land owned & $9.40(5.45)$ & 1.73 & $0.084^{*}$ & 0.000032 \\
\hline Education & $-5.51(5.44)$ & -1.01 & 0.310 & -0.000017 \\
\hline Sacks taken to option & $5.87(3.03)$ & 1.94 & $0.053^{*}$ & 0.0000194 \\
\hline Value addition done & $-3.35(2.84)$ & -1.18 & 0.238 & -0.0000129 \\
\hline Age & $4.42(8.08)$ & 0.55 & 0.584 & 0.0000194 \\
\hline Gender & $8.50(4.71)$ & 1.80 & $0.071^{*}$ & 0.0002025 \\
\hline \multicolumn{5}{|c|}{ MAINMKT = Village market outlet is the base outcome } \\
\hline \multicolumn{5}{|c|}{ Number of observations $=68$} \\
\hline \multicolumn{5}{|l|}{ LR chi $2(20)=91.05$} \\
\hline \multicolumn{5}{|l|}{ Log likelihood $=-29.179805$} \\
\hline \multicolumn{5}{|l|}{ Prob $>X^{2}=0.0000$} \\
\hline Pseudo $R^{2}=0.6094$ & & & & \\
\hline
\end{tabular}

*Significance levels at 10\%; Figures in parentheses () are standard errors.

household needs to be met from the same limited resources, such that their behavior may not be identical to that of a firm. This implies that other studies of different populations may be needed to understand better this unique behavior.

The results indicate that the number of sacks taken to the market positively influences local town market participation. As the number of sacks the farmer takes to market increases by $1 \mathrm{bag}$, the probability of participating in local town than village increases by $23.5 \%$. The increase in sacks taken to the market will make the farmer sell his produce in the local market which has a larger population of buyers hence increasing his chances of selling most or all of his produce as compared to the village which has less.

Total income which is a summation of both farm and off-farm sources positively influences local town market participation. An increase in the monthly income by $1 \%$ increases the probability of participating in the local town market than village by $22.2 \%$. The increase in cash resources will make the farmer invest more in sweet potato production and marketing activities resulting to more surplus driving him to sell to local town which is a larger market compared to village.

On transport mode used to reach the market, the results show that it positively influences local town market participation. As the transport mode becomes better in terms of quick access to the market, affordability and 
convenience (collecting produce from home and carrying many bags at a time), the probability of participating in local town than village increases by $28.7 \%$. Good transport reduces transportation costs for the farmer and hence makes it easy and cheaper for him/her to access local town market which has better market conditions in terms of big population of buyers and sellers and better prices compared to the village market option (Machethe et al., 2008).

Access to extension positively influences local town market participation such that, a change in a farmer's status from no access to extension to access increases the probability of local town market participation than village by $44.6 \%$. This implies that extension will make the farmer participate more in the local town than the village market option. Extension services enable the farmer to improve his production methods hence leading to more output which in turn increases his/her marketed surplus hence market participation (Lapar et al., 2002), especially in larger markets such as local town.

Value addition done by the farmer does positively influence participation in local town market. If the farmer changes his value addition activities to include sorting, washing and packaging from otherwise, the probability of participating in local town market than village increases by $22 \%$. Because of presence of many sellers in the local town compared to village, farmers have to ensure that their products are appealing to the buyers and hence have competitive advantage over other sellers.

Age of the farmer negatively influences local town market participation. This implies that an increase in the age by 1 year decreases the probability of participating in the local town than village market by $72.7 \%$. This is inconsistent with the expected positive priori sign according to Machethe et al. (2008) such that, as the farmer gets old he will choose to participate less in the local town market than the village market option because of the loss in energy to sell in distant markets.

Results for the socio-economic factors determining participation in the regional markets, show that transport used to reach the regional market positively influences participation. An improvement in transport increases probability of participation in the regional market than the village market. Good transport acts as an incentive for farmers to sell to distant markets, which usually have better market conditions, because it reduces the cost of transportation and hence increases the farmers' profit margins.

Total land owned positively influences participation in the regional option. An increase in land owned increases the probability of participating in regional as compared to the village market. This is consistent with Machethe et al. (2008) who find that larger land sizes raise the probability of market participation for sellers since land is a critical production asset having a direct bearing on production of a marketable surplus, ceteris paribus. This implies that those with large tracts of land are likely to participate more in markets especially larger ones such as regional.
The sacks taken to the market positively influences regional market participation. An increase in the number of sacks increases the probability of farmers participating more in the regional market than village. As the number of sacks increases, farmers are likely to participate more in the regional than village market option because more sacks implies more economies of scale and hence it is better to sell to far away markets where prices are good.

Gender positively influences participation in the regional option and is significant at $10 \%$ level. As the gender of the participant changes from female to male, the probability of participating in the regional option being higher for male, implying that male farmers are likely to participate more in the regional market option than the village. Despite sweet potato production and marketing being mainly done by women (Nungo et al., 2007), men usually influence participation in distant market options such as regional.

In conclusion it can therefore be stated that the shift in participation of smallholder sweet-potato farmers from village market to a more income generating regional market is determined by; increased household income, land size, transport mode, gender of farmer, output of sweet-potato, extension services and value addition made.

\section{Policy implications}

Sweet potato production and marketing activities are mainly done by women in Vihiga County. To reduce poverty, the Government through agricultural officers, Non-governmental organizations and other stakeholders should first identify which member of the household has control over the crop in question then offer interventions which will take into consideration the gender of the person. For instance, if the interventions include programs such as giving financial aid to the farmers, they ought to take into consideration that most of these female farmers do not have collateral since title deeds and other property in most cases are in the name of their husbands who are less likely to allow the titles to be used as collateral.

The most common market option for majority of the farmers is the village market because of its close proximity that makes farmers to incur lower transportation costs. Consequently, the prices and income in this market are low because of the excess supply. Formal or informal institutional arrangements such as farmer groups or organizations should be encouraged through which farmers can collectively access distant markets which have good prices. The arrangements will facilitate: use of common transport; exchange of marketing information while strengthening negotiation; bargaining position of farmers, and; also make contracting and enforcement of contracts easier.

The size of the land owned was found to be low while the population in the area is high hence putting pressure 
on the land resources. To increase land productivity, the government needs to provide farmers with high yielding and disease resistant sweet potato varieties. The government also needs to avail extension officers in the area so as to advice farmers on new farming techniques.

Since transport costs reduce market participation, the government should increase investment in the rural road transport network so as to ease movement of goods and reduce the transportation costs.

\section{REFERENCES}

Asfaw S, Amare M, Lipper L, Davis B, Simtowe F (2010). Smallholder market participation and rural poverty; evidence from tanzania and ethiopia. www.csae.ox.ac.uk/conferences/2011-EDiA/papers/306Asfaw (accessed on $30^{\text {th }}$ June, 2011).

CPPMU (2010). Economic review of agriculture. Central Planning and Project Monitoring Unit, (CPPMU), Ministry of Agriculture, Nairobi.

FAO (2007). Food Security Profiles. Food and Agriculture Organization, Nairobi, http://www.fao.org (Accessed on $17^{\text {th }}$ July 2010).

Greene WH (2002). Econometric Analysis. $5^{\text {th }}$ Ed. Pearson Education Inc., New Jersey.

Karanja F (2006). Cropwat model analysis of crop water use in six districts in Kenya. Department of Meteorology, University of Nairobi, Nairobi.

Komarek A (2010). The determinants of banana market commercialization in Western Uganda. Afr. J. Agric. Res. 5(9):775784.

Lapar ML, Holloway G, Ehui S (2002). Policy options promoting market participation of smallholder livestock producers: A case study of the Philippines. Socio-economic and Policy Research Working Paper 47. ILRI, Nairobi.
Machethe C, Jagwe J, Ouma E (2008). Transaction costs and smallholder farmers' participation in banana markets in the Great Lakes Region. Department of Agricultural Economics, Extension and Rural Development, University of Pretoria.

MOPND (2005). Vihiga District Strategic Plan 2005-2010: for implementation of the national population policy for sustainable development. National Coordination Agency for Population and Development, Ministry of Planning and National Development (MOPND), Nairobi.

Mugisha J, Mbowa S, Kasibante F (2004). Determinants of use of Information and Communication Technologies by Agribusiness Firms in Uganda. East Afr. J. Rural Dev. 20:0377-7103.

Nungo RA, Ndolo PJ, Kapinga R, Agili S (2007). Development and promotion of sweet potato products in Western Kenya. Proceedings of the $13^{\text {th }}$ ISTRC symposium. pp. 790-794.

Nyangweso O (2007). Household food security in Vihiga District, Kenya; Determinants of dietary diversity. African Crop Science Proceedings. 8:1383-1389.

Olwande J, Mathenge M (2010). Market participation among rural poor households in Kenya. Tegemeo Institute, Egerton University, Nairobi.

Omiti JM, Otieno DJ, Nyanamba TO, McCullough E (2009). Factors influencing the intensity of market participation by smallholder farmers; A case study of rural and peri-urban areas of Kenya. AFJAE, 3(1):71-82; http://www.kippra.or.ke (Accessed on $28^{\text {th }}$ March, 2011).

Rono SC, Wanyama JM, Mose LO, Mutoko CM, Chesoro J, Lusweti CM, Wanjecheke E, Wachige B (2007). Assessing Household Sweet Potato-based Diet among Rural Communities in North Rift Region of Kenya. http://www.kari.org. 